\title{
Effectiveness of Structured Teaching Program regarding Prevention of Needle Stick Injury among Nursing Students
}

\author{
Lavanya Nandan', Shilpa Katoch ${ }^{2}$ \\ ${ }^{1}$ Principal, ${ }^{2}$ Lecturer, Nightingale Institute of Nursing, Noida, Uttar Pradesh, India. \\ DOI: https://doi.org/10.24321/2348.2133.201904
}

\section{I $\quad \mathbf{N} \quad \mathbf{F} \quad \mathbf{O}$}

\section{Corresponding Author:}

Lavanya Nandan, Nightingale Institute of Nursing, Noida, Uttar Pradesh, India.

E-mail Id:

mihirdas90@gmail.com

Orcid Id:

https://orcid.org/0000-0002-3900-2957

How to cite this article:

Nandan L, Katoch S. Effectiveness of Structured

Teaching Program regarding Prevention of Needle

Stick Injury among Nursing Students. Ind J Holist

Nurs 2019; 10(1): 27-30.

Date of Submission: 2019-07-29

Date of Acceptance: 2019-11-04

\section{$\begin{array}{llllllll}\mathbf{A} & \mathbf{B} & \mathbf{S} & \mathbf{T} & \mathbf{R} & \mathbf{A} & \mathbf{C} & \mathbf{T}\end{array}$}

A pre-experimental study was conducted to assess the effectiveness of structured teaching program regarding prevention of needle stick injury among nursing students in selected college of nursing, Noida. 30 samples were selected and data collection was done through questionnaire. Descriptive and inferential statistics were used for data analysis. Study Results showed that the mean post test score (14.733) was higher than the mean pre-test score (10.166) with the mean difference of 4.567 . Therefore, the structured teaching program was an effective method for improving the knowledge on the prevention of needle stick injury.

Keywords: Needle stick injury, Nursing, Structured teaching program

\section{Introduction}

A needle stick injury is a percutaneous piercing wound typically set by a needle point but possibly also by other sharp instruments or objects. Nurses are much prone to get these injuries. It is considered as an occupational hazard. These are of concern because it can cause blood borne diseases such as Hepatitis B, C and Human Immunodeficiency Virus (HIV). ${ }^{1}$

As per nursing curriculum, they are not usually allowed to push injections officially in first year and in second year they start giving injections after being properly trained about safe injection practices. It is important for them to be aware about safe injection practices. According to researchers, teaching them will help them to memorize and practice the safety measures regarding prevention and post exposure prophylaxis of needle stick injury. ${ }^{2}$
Despite of their seriousness as a medical event, needle stick injuries have been neglected and most go unreported. On the other hand, as needle stick has been recognized as occupational hazards, their prevention has become the subject of regulations in an effort to reduce and eliminate this preventable event. ${ }^{3}$

\section{Problem Statement}

"A Study to Assess the Effectiveness of Structured Teaching Program Regarding Prevention of Needle Stick Injury Among B. Sc Nursing Students in Selected College of Nursing, Noida".

\section{Objectives}

The objectives of the study were:

- $\quad$ To assess the pre-interventional knowledge regarding prevention of needle stick injury among nursing 
students of selected college of nursing, Noida.

- To assess the effectiveness of structured teaching program on knowledge regarding prevention of needle stick injury among nursing students of selected college of nursing, Noida.

- To find out the association between the post- test knowledge score and selected demographic variables.

\section{Hypothesis}

$\mathbf{H}_{\mathbf{0}}$ : There will be no significant difference in pre-test and post-test knowledge score on prevention of needle stick injury among the B. Sc (N) II-year students at 0.05 level of significance.

$\mathbf{H}_{1}$ : There will be significant difference in pre-test and post-test knowledge score on prevention of needle stick injury among the B. Sc (N) II-year students 0.05 level of significance.

$\mathbf{H}_{2}$ : There will be significant association between levels of knowledge scores and selected demographic variables 0.05 level of significance.

\section{Methodology}

- Research Approach: The quantitative research approach was adopted for the study.

- Research Design: Pre-experimental one group pre-test post-test research design was used during the conduct of the study.

- Setting: Research setting was the Nightingale Institute of Nursing, Sector-62, Noida, Uttar Pradesh, India.

- Sample Size and Technique: 30 students of B. Sc (N) $2^{\text {nd }}$ year of the Nightingale Institute of Nursing were selected by using random sampling technique.

- Tool: Knowledge questionnaire was used to collect the data.

\section{Inclusion Criteria}

Nursing students, who were:

- In B.Sc. Nursing 2nd year

- Studying in Nightingale institute of nursing, Noida

\section{Exclusion Criteria}

Nursing students, who were:

- $\quad$ Studying in B.Sc. Nursing $1^{\text {st }}$ year, B.Sc. Nursing $3^{\text {rd }}$ year and B.Sc. Nursing $4^{\text {th }}$ year.

- Enrolled in other programes like GNM, P.B.BSc. And M.Sc Nursing.

- Studying in colleges other than Nightingale Institute of Nursing, Noida.

\section{Study Period}

- The study was conducted from 05/02/19 to 25/02/19.

\section{Result}

Table I.Findings related to frequency and percentage distribution of prevention of needle stick injury to describe demographic characteristics

$(\mathrm{N}=30)$

\begin{tabular}{|c|c|c|c|}
\hline \multirow{2}{*}{$\begin{array}{l}\text { Demographic } \\
\text { characteristics }\end{array}$} & \multicolumn{2}{|c|}{$\begin{array}{l}\text { Prevention of needle } \\
\text { stick injury }\end{array}$} & \multirow{2}{*}{$\begin{array}{c}\text { Chi-square } \\
\quad\left(x^{2}\right)\end{array}$} \\
\hline & $\begin{array}{l}\text { Frequency } \\
\text { (f) }\end{array}$ & \begin{tabular}{|c|} 
Percentage \\
(\%)
\end{tabular} & \\
\hline \multicolumn{4}{|c|}{ Age (in years) } \\
\hline $18-20$ & 27 & $90 \%$ & \multirow{3}{*}{$\begin{array}{c}\chi^{2}=0.792 \\
(N / S)\end{array}$} \\
\hline $21-23$ & 3 & $10 \%$ & \\
\hline 24 \& above & 0 & $0 \%$ & \\
\hline \multicolumn{4}{|c|}{ Gender } \\
\hline Female & 30 & $100 \%$ & \multirow{2}{*}{$\chi^{2}=0(N / S)$} \\
\hline Male & 0 & $0 \%$ & \\
\hline \multicolumn{4}{|c|}{ Educational qualification } \\
\hline GNM & 0 & $0 \%$ & \multirow{4}{*}{$\chi^{2}=0(N / S)$} \\
\hline B. Sc nursing & 30 & $100 \%$ & \\
\hline $\begin{array}{c}\text { Post B. Sc } \\
\text { nursing }\end{array}$ & 0 & $0 \%$ & \\
\hline M. Sc nursing & 0 & $0 \%$ & \\
\hline \multicolumn{4}{|c|}{$\begin{array}{c}\text { Have you } \\
\text { experienced NSI? }\end{array}$} \\
\hline Yes & 7 & $23 \%$ & \multirow{2}{*}{$\begin{array}{c}\chi^{2}=0.048 \\
(N / S)\end{array}$} \\
\hline No & 23 & $77 \%$ & \\
\hline \multicolumn{4}{|c|}{ Previous knowledge } \\
\hline Yes & 22 & $73 \%$ & \multirow{2}{*}{$\begin{array}{c}\chi^{2}=0.368 \\
(N / S)\end{array}$} \\
\hline No & 8 & $27 \%$ & \\
\hline
\end{tabular}

Table 1 represents the following findings:

- Majority of the subjects $90 \%$ (27) were in the age group of $18-20$ years, $10 \%$ (3) were in the age group of 21-23 years.

- Majority of the subjects $100 \%$ (30) were females.

- Majority of the subjects $100 \%$ (30) were in B.sc Nursing.

- Majority of the subjects, 23\% (7) were experienced Needle Stick Injury, 77\% (23) were not experienced Needle Stick Injury.

- Majority of the subjects $73 \%$ (22) were having previous knowledge, $27 \%$ (8) were not having previous knowledge.

Data presented in Table 2 shows that in post-test, majority of the subjects $80 \%(24)$ were having good marks and $20 \%(6)$ were having excellent marks. 
Table 2.Frequency and percentage distribution of pre-test and post-test of prevention of needle stick injury

\begin{tabular}{|c|c|c|c|c|}
\hline \multirow{2}{*}{ Scoring } & \multicolumn{2}{|c|}{ Pre-test Score } & \multicolumn{2}{c|}{ Post-test Score } \\
\cline { 2 - 5 } & Frequency (f) & Percentage (\%) & Frequency (f) & Percentage (\%) \\
\hline $0-8$ (Average) & 3 & $10 \%$ & 0 & $0 \%$ \\
\hline $9-16$ (Good) & 27 & $90 \%$ & 24 & $80 \%$ \\
\hline $17-25$ (Excellent) & 0 & $0 \%$ & 6 & $20 \%$ \\
\hline
\end{tabular}

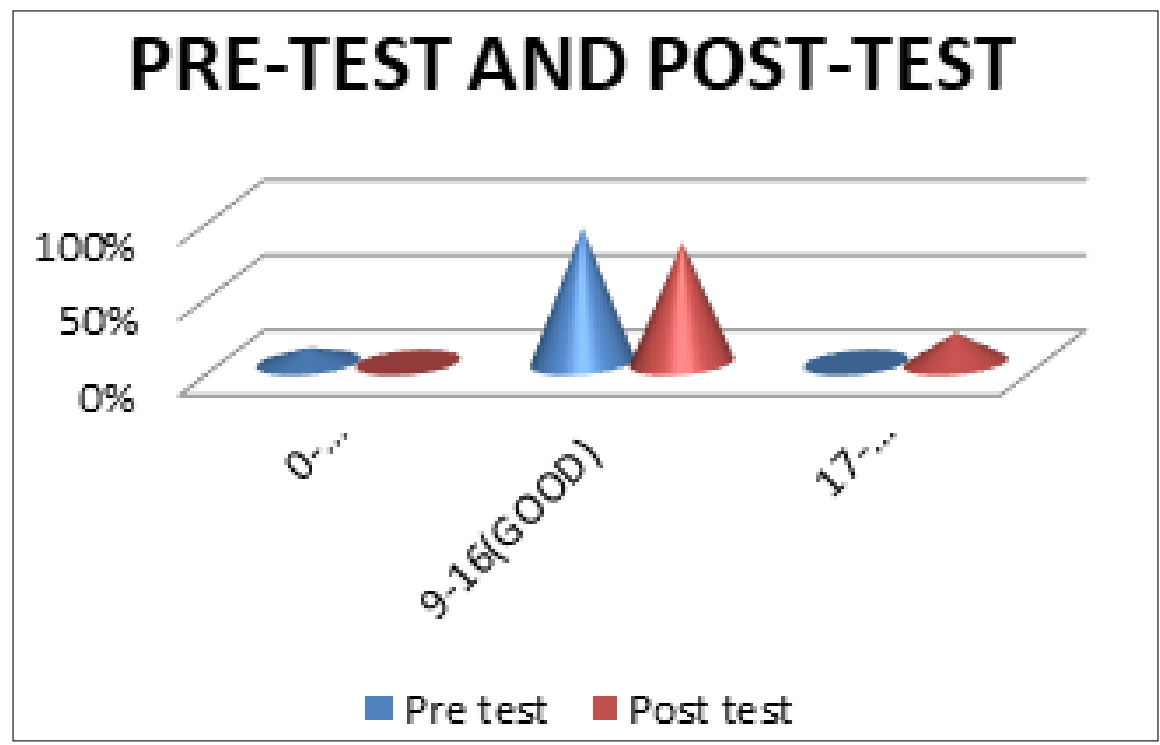

Figure I.Represents the pre-test and post-test score

Table 3.Mean, median, mean difference, standard deviation and ' $t$ ' value of pre-test and posttest scores in prevention of needle stick injury

$(\mathrm{N}=30)$

\begin{tabular}{|c|c|c|c|c|c|}
\hline B. Sc nursing $2^{\text {nd }}$ year & Mean & Median & Mean difference & S.D & “ $t$ " Value \\
\cline { 1 - 3 } Pre-test & 10.166 & 9 & 4.567 & 2.097 & \\
\cline { 1 - 3 } Post-test & 14.733 & 14 & & 2.44 & $\mathrm{t}=7.96$ \\
\hline
\end{tabular}

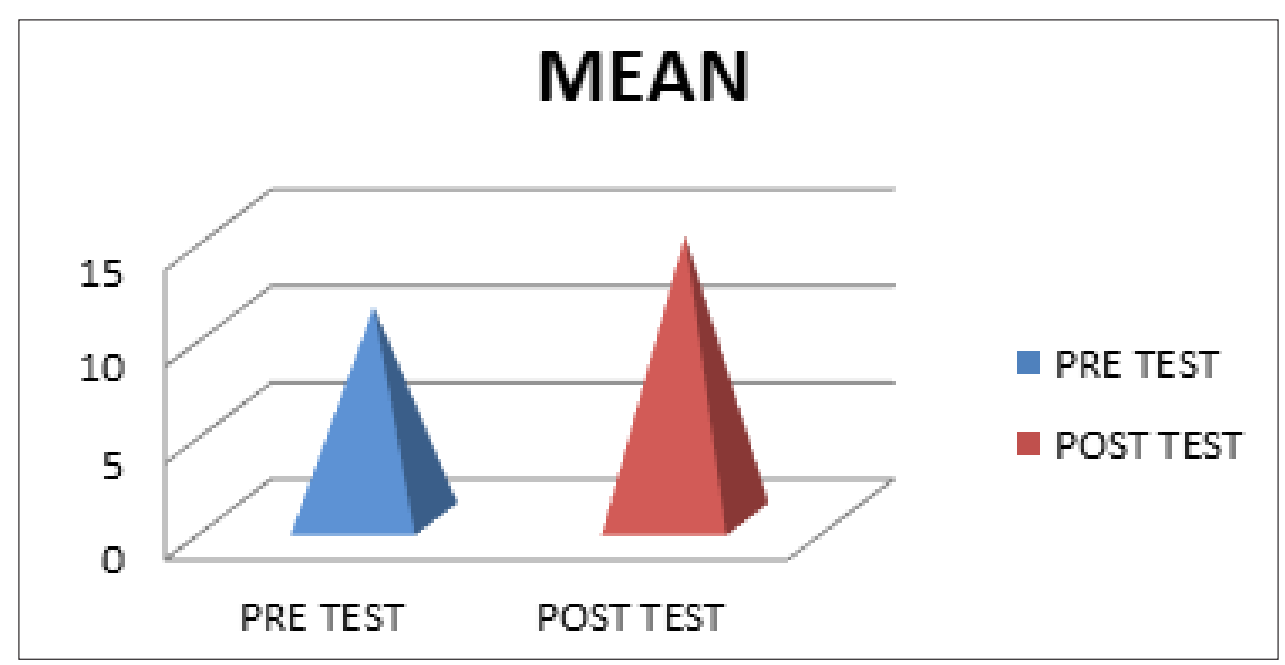

Figure 2.Represents the mean pre-test and mean post-test score 
Data represented in table 3 shows that the mean post test score (14.733) of bsc $2^{\text {nd }}$ year is higher than the mean pre test score (10.166), with the mean difference of 4.567 . The obtained mean difference was found to be statistically significant as evident from the ' $t$ ' value of (7.96) for df at 0.05 significance which is greater than the table value (1.729).

\section{Discussion}

These injuries can occur at any time when people use, disassemble, or dispose of needles. When not disposed of properly, needles can hide in linen or garbage and injure other workers who encounter them unexpectedly.

The present study finding revealed that structured teaching programme was found to be an effective method for improving the knowledge of nursing students regarding prevention of Needle Stick Injury.

In this study the mean post test score (14.733) of bsc $2^{\text {nd }}$ year is higher than the mean pre test score (10.166), with the mean difference of 4.567 . The obtained mean difference was found to be statistically significant as evident from the ' $t$ ' value of (7.96) for df at 0.05 significance which is greater than the table value (1.729) . It can be inferred that structured teaching program was effective method for increasing knowledge regarding the prevention of needle stick injury.

\section{Nursing Implications}

The present study has several implications in nursing practice, nursing research, nursing administration and nursing education.

\section{Nursing Practice}

- The findings of the present study will help the B.sc 2nd year $(\mathrm{N})$ students to enlighten their knowledge regarding prevention on needle stick injury.

- $\quad$ B.sc nursing students will be encouraged to use safety devices in order to prevent needle stick injuries as these are safe, economic, and easy way to dispose needles.

\section{Nursing Research}

- There is a need for extensive and intensive research in methods of prevention of needle stick injury so that strategies for educating nurse regarding prevention of injuries can be implemented.

- This study can be used as an access for further studies.

\section{Nursing Administration}

- The nursing administration should organize educational programme for the nursing students and nursing staff to update the knowledge related to advanced information regarding prevention of needle stick injury for reducing the incidence of these injuries.

- Reading materials, reference books and nursing manuals must be made available for the student nurses regarding prevention of needle stick injury for administering evidence-based practices.

- $\quad$ The administrator must see that every nurse has adequate knowledge and skills in handling the sharp materials and using the safety devices.

\section{Nursing Education}

- $\quad$ Specialized courses in handling the sharp containers and using the safety devices can be introduced to train nurse specialists.

- Nursing curriculum should include these topics to sensitize the student nurse.

- $\quad$ Findings of the study will help the nursing students to understand the importance of needle stick injury.

\section{Conclusion}

Structured teaching program was an effective intervention to improve the knowledge of B. Sc (N) $2^{\text {nd }}$ year students as study results showed that the mean post-test score (14.733) was higher than the mean pre-test score (10.166) with the mean difference of 4.567 which was found statistically evident from the ' $t$ ' value (1.729). Therefore, the structured teaching program was an effective method for improving the knowledge on prevention of needle stick injury.

\section{Conflict of Interest: None}

\section{References}

1. Saini R. Knowledge and awareness of needlestick injury among students of Rural Dental College, Maharashtra, India. Ann Nigerian Med [serial online] 2011 [cited 2019 Sep 28];5:12-4. Available from: http://www.anmjournal. com/text.asp?2011/5/1/12/84221.

2. Mitra SP, Malik S, Das M et al. INJECTION safety: perception and practice of nursing students in tertiary setting [serial online] 2011 [cited 2019 March 28];41:34. Available from: http://medind.nic.in/ibl/t10/i3/ iblt10i3p185.pdf.

3. Phillips EK, Conaway M, Parker $\mathrm{G}$ et al. Issues in understanding the impact of the needle stick safety and prevention act on hospital sharps injuries. Infection Control and Hospital Epidemiology 2003; 34(9): 935939. [PubMed/ Google Scholar]. 